\title{
The emergence of the Black Methodist Consultation and its possible prophetic voice in post-apartheid South Africa
}

\begin{tabular}{|c|}
\hline $\begin{array}{l}\text { Author: } \\
\text { Ndikho Mtshiselwa }{ }^{1}\end{array}$ \\
\hline $\begin{array}{l}\text { Affiliation: } \\
{ }^{1} \text { Department of Biblical and } \\
\text { Ancient Studies, University of } \\
\text { South Africa, South Africa }\end{array}$ \\
\hline $\begin{array}{l}\text { Correspondence to: } \\
\text { Ndikho Mtshiselwa }\end{array}$ \\
\hline $\begin{array}{l}\text { Email: } \\
\text { mtshivnn@unisa.ac.za }\end{array}$ \\
\hline $\begin{array}{l}\text { Postal address: } \\
\text { PO Box 392, Unisa, Pretoria } \\
\text { 0003, South Africa }\end{array}$ \\
\hline $\begin{array}{l}\text { Dates: } \\
\text { Received: } 23 \text { Jan. } 2015 \\
\text { Accepted: } 11 \text { Mar. } 2015 \\
\text { Published: } 04 \text { June } 2015\end{array}$ \\
\hline $\begin{array}{l}\text { How to cite this article: } \\
\text { Mtshiselwa, N., 2015, 'The } \\
\text { emergence of the Black } \\
\text { Methodist Consultation and } \\
\text { its possible prophetic voice in } \\
\text { post-apartheid South Africa', } \\
\text { HTS Teologiese Studies/ } \\
\text { Theological Studies 71(3), } \\
\text { Art. \#2897, } 9 \text { pages. http:// } \\
\text { dx.doi.org/10.4102/hts. } \\
\text { v71i3.2897 }\end{array}$ \\
\hline $\begin{array}{l}\text { Copyright: } \\
\text { (C) 2015. The Authors. } \\
\text { Licensee: AOSIS } \\
\text { OpenJournals. This work is } \\
\text { licensed under the Creative } \\
\text { Commons Attribution } \\
\text { License. }\end{array}$ \\
\hline
\end{tabular}

Racism is an issue which the activism of the Black Methodist Consultation (BMC) was set to address during the South African apartheid rule, a view which black theologians and church historians generally accept. This observation brought to mind, in turn, the influence that the Black Consciousness philosophy and the black theology of liberation had on the establishment of the BMC. Recounting such an influence, this article provides a reflection on the formation of the BMC in 1975. In such a reflection, the hypothesis is that the prophetic voice of the BMC is crucial in post-apartheid South Africa. Firstly, the interconnectedness of the Black Consciousness philosophy, the black theology of liberation and the BMC is highlighted. Secondly, the article proceeds to navigate the possible prophetic voice of the BMC in postapartheid South Africa. In the end, this article sees the BMC as a crucial interlocutor of liberation in present South Africa.

\section{Introduction}

The year 2015 marks the 40th year of the Black Methodist Consultation's (BMC) existence and activism. In the years of its existence, the positive contribution made by the BMC in South Africa is indisputable. As Forster (2011) excellently observed, the BMC has offered a significant prophetic contribution in the following instances:

The 1985 'one and undivided' statement; the 1981 'obedience' conference that informed the Church's civil disobedience against unjust apartheid laws; and the 'journey to the New Land' of the early 1990 that paved the way for racial reconciliation and social transformation leading up the 1994 democratic elections. (p. 46; cf. Methodist Church of Southern Africa 1958:202; 1982:379)

The intention of the present article is not to recite the historic prophetic voice and the contribution made by the BMC, but to provide a reflection which leads us to a realisation of the prophetic voice that the BMC could articulate in South Africa today. However, suffice it to note, the civil disobedience against apartheid laws defined the prophetic voice of the BMC as documented in the Minutes of Conference of the Methodist Church of Southern Africa (cf. Methodist Church of Southern Africa 1958:202; 1982:379). First and foremost, the black theology of liberation cannot easily be discussed without making mention of the Black Consciousness philosophy, as they are interconnected (Pang 2007:117-118). There is evidence of the relationship between the black theologians of liberation, the Black Consciousness philosophers and the BMC (cf. Denis \& Duncan 2011:85; Duncan 2013:61, 63; Kretzschmar 1986:61), as will be discussed later these link the BMC to the preceding interconnectedness. As such, it seems that the objectives of the BMC cannot be completely understood outside the discourse on the black theology of liberation and the Black Consciousness philosophy. Therefore, the article will first present a discussion about the interconnectedness of the Black Consciousness philosophy, the black theology of liberation and the BMC. Secondly, the prophetic voice of the BMC in South Africa will be navigated with a view to present the possible prophetic role that the BMC may consider.

The hypothesis of this article is: The prophetic voice of the BMC is crucial in post-apartheid South Africa. Towards this hypothesis, the literature on the BMC, the black theology of liberation and the Black Consciousness philosophy will be explored.

\section{Interconnectedness of the Black Consciousness philosophy, the black theology of liberation and the Black Methodist Consultation}

The view that the BMC emerged as an activist formation within the Methodist Church of Southern Africa (MCSA) that sought to redress racism during the apartheid rule in South Africa, is not 
only conclusive, but generally accepted. What is often not accepted, as will be shown later, is the view that the reflection on the formation of the BMC is silent on the impact that the Black Consciousness philosophy and the black theology of liberation had on the establishment the BMC. Thus, it is argued here that a reflection on the interconnectedness of the Black Consciousness philosophy, the black theology of liberation and the BMC could shed valuable light on the objectives of the BMC.

\section{Black Consciousness philosophy}

Of significance is the argument that the black theology of liberation was enthused by the work of James Hal Cone who in the United States of America (USA) was impressed by the civil rights movement, the prophetic voice of Martin Luther King Jr, and the critique of racism on the part of white people by Malcolm X (Motlhabi 2007:7). Based on such an argument, the interconnectedness of the Black Consciousness philosophy, the black theology of liberation and the prophetic voice of the BMC, is indisputable. Interestingly, the then University Christian Movement (UCM) in 1971 placed the black theology of liberation in the lime light in South Africa. Thus, it is argued that the black theology of liberation was strongly articulated in the light of the Black Consciousness Movement in South Africa with a view to critique racism (Motlhabi 2007:7; cf. De Gruchy \& De Gruchy 2004:144-164; Tshaka 2010b:540; West 2010:161). Therefore, the struggle against racism links the Black Consciousness philosophy and the black theology of liberation.

As Biko excellently perceived, the Black Consciousness philosophy insists on redress of the oppression of black South Africans based on race (Biko 2004:49; cf. Mgojo 1977:28). Masenya (ngwan'a Mphahlele) (2004:69) employs the phrase, African-South Africans, to refer to indigenous (black) people of South Africa who are of African descent, namely, the persons whose home language is Xhosa, Ndebele, Sotho, Tswana, Zulu, Venda and so forth. Although the preceding phrase makes sense, the phrase black South Africans is however used here as it is germane to the present discourse of the Black Consciousness philosophy and the black theology of liberation and the BMC. That the oppression of black South Africans in the system of colonialism and apartheid was based on race resonates with the view that the Black Consciousness philosophy insists on the redress of racism. Furthermore, in light of Black Consciousness philosophy, the struggle of black South Africans 'to rid themselves of the shackles that bind them to perpetual servitude' places the focus on the person who accepted the position of servitude (Biko 2004:49). Instead of being concerned about the oppressor, the Black Consciousness philosophy focuses on the oppressed black South Africans who self-permitted the situation of perpetual subordination to the oppressor. Therefore, this philosophy sought to liberate black South Africans from both their inferiority complex and the servitude mentality which resulted in the acceptance of their oppression. Furthermore, a critical position on the function of the Black Consciousness philosophy is that:

The first step therefore is to make the black man come to himself; to pump back life into his empty shell; to infuse him with pride and dignity, to remind him of his complicity in the crime of allowing him to be misused and therefore letting evil reign supreme in the country of his birth. (Biko 1979:29)

Based on the view that the black man should come to himself, Biko supposes a situation of flight from the black self. On his part, Tshaka (2014:3) describes the flight from the black self as the lack of being organically linked with the cultural lives of black South Africans which is noticeable both in the abandonment of black institutions and the preoccupation with Euro-American intellectual products (Carter 2010:48; Isaacs 1975:127; Tshaka 2009:9; 2010a:124-125; West 1999b:305). Put differently, the flight from the black self is manifested in the negation of blackness and affirmation of whiteness.

Worthy of note is the objective that seeks, 'to infuse him (i.e. a black South African) with pride and dignity' (Biko 1979:29). Following Himes, Duncan (2013:61-62) decisively argues that the Black Consciousness philosophy is set to lead black South Africans to the realisation that racism created self-hatred, as they came to believe that the designation 'black' was a symbol of sinfulness and ugliness (Himes 1971:55). Subsequently, the preceding philosophy was established with a view to address the sense of inferiority and worthlessness among black South Africans that came with the designation 'black', as will be shown below. It is interesting to note that the realisation of the impact of racism on self-hate was created by the slogan, 'black is beautiful' which challenged self-negation - a kind of feeling of self-censure within the black man (Woods 1978:191; 1987:55). In other words, such a slogan challenged self-hate and self-alienation as it sought to enable black South Africans to love themselves (Masenya [ngwan'a Mphahlele] 2008:120).

Furthermore, on the one hand, the idea that the Black Consciousness philosophy sought to identify white oppressive socio-economic structures during the apartheid rule in South Africa is attractive (Goba 1986:66; Tshaka 2010b:540). Such a view suggests, in part, that the apartheid government oppressed many a black South African based on race. In this case, the Black Consciousness philosophy finds some of the white persons guilty for the oppression of black South Africans. On the other hand, Biko's observation of the complicity of black South Africans in their situation of oppression is appealing as it holds black people accountable for their oppression (Biko 1979:29). That the Black Consciousness philosophy was set to draw to light the way black South Africans self-inflicted their oppression in how they allowed racism to advance in South Africa supports the preceding observation. Also, the fact that Biko's position here does not blame white persons for the oppressive effects of racism on black South Africans is appealing. Interestingly, neither does Biko make a caricature of blackness as being bitter towards the apartheid government for the oppression 
of black South Africans. Therefore, based on Biko's view of the Black Consciousness philosophy, the argument that it was the responsibility of the oppressed to resist their oppression is compelling (Wilson 1991:23).

No doubt, an appreciative critique of Biko's position on the Black Consciousness philosophy provides a convincing conceptualisation of this philosophy. The Black Consciousness philosophy insists on the redress of the oppression of Africa-South Africans, based on race. This philosophy refutes the negation of blackness and the affirmation of whiteness. It equally demands the infusion of black South Africans with pride and dignity. Furthermore, whilst the Black Consciousness philosophy identifies the manner in which white people were oppressive in apartheid South Africa, it also critiques the complicity of black South Africans.

\section{Black theology of liberation}

It may be difficult to construe the black theology of liberation in South Africa apart from the Black Consciousness philosophy (Pang 2007:117-118). The view that the black theology of liberation emerged within the context of the Black Consciousness Movement of South Africa as a critique of racism validates the preceding point (Motlhabi 2007:7; cf. De Gruchy \& De Gruchy 2004:144-164; Tshaka 2010:540; West 2010:161). Intriguingly, Gqubule, a black Methodist minister and theologian, views the black theology of liberation as 'an attempt to present the Christian gospel to the black man relevantly with all its liberating power' (Gqubule 1974:18). In such an attempt, the black theology of liberation views the oppression of black South Africans as bearing a striking resemblance to the crucifixion of Christ. Based on the preceding view, the implication of the event of Jesus' death and resurrection is the pursuit of freedom (cf. Cone 1992:21; Gqubule 1974:18). Put differently, the black theology of liberation insists that the oppressed people move from a situation of being trapped in the system of oppression towards the realisation of liberation which is depicted in the resurrection of Christ. Furthermore, the black theology of liberation demands that black South Africans identify with the resurrected Christ who was crucified. The preceding demand resonates with the argument made by Biko that the oppressed black South Africans struggle for their liberation (Biko 1979:29). On the latter point, there is a clear connection between the Black Consciousness philosophy and the black theology of liberation.

Significantly, the Black Consciousness philosophy was popularised by Steve Biko who, in turn, was influential in the seminary circles (Duncan 2013:63; cf. Denis \& Duncan 2011:85). Not only was Biko active at the Federal Theological Seminary of Southern Africa (FEDSEM), he was equally a member of the UCM which made the project of the black theology of liberation a success in South Africa (Duncan 2013:61; Kretzschmar 1986:61). Clearly, the argument that the black theology of liberation constituted the religious complement to the Black Consciousness philosophy is warranted. As De Gruchy correctly perceived, the Black Consciousness philosophy as well as the black theology of liberation had a considerable bearing on the development and the activism of the ministers who were trained at the FEDSEM (De Gruchy 1997:164). Nonetheless, a critical question to ask is: What bearing did the Black Consciousness philosophy and the black theology of liberation, have on the establishment the BMC?

\section{Imagining the $\mathrm{BMC}$ in light of the Black Consciousness philosophy and the black theology of liberation}

In the USA, Hopkins points out that black activism against racism rose when the black theologians of liberation jointly worked with political activists and the black churches (Hopkins 1990:93). Similar to the preceding context, the BMC emerged from an interaction between black South African political activists, the black theologians of liberation and the black ministers in the MCSA with a view to redress racism. Various reasons for the formation of the BMC have been proposed by both church historians and theologians. For instance, it is claimed that the BMC was established with the aims of promoting black thinking; to develop black leadership; to respond to the issue of racism; to work against the segregation and apartheid; and to address the exclusion of black ministers from the decision-making processes of their church (cf. Bentley 2014:4; Forster 2008:11-12; Pritchard 2014:285; Theilen 2003:28). Significantly, the preceding aims to define the prophetic voice of the BMC at the time of its emergence. Notwithstanding the merit of the prophetic voice of the BMC during the apartheid regime, the intention here is not necessarily to recount the reasons for the establishment of the BMC, but to argue that the Black Consciousness philosophy and the black theology of liberation had a significant influence on the formation of the BMC.

The view that the BMC was formed in order to promote black thinking and leadership in a church which was dominated at the time by white leadership appears attractive (VillaVicencio 1996:194). Based on this view, it may be argued that the BMC sought to address the mental state of the oppressed black South Africans. That the BMC laid the ground for the awareness of blackness which in turn was meant to undo the psychological oppression of black South Africans that was born out of the system of apartheid lends, credence to the preceding view (Theilen 2003:28). It is therefore reasonable to argue that the apartheid system adversely affected black South Africans. The submission that the BMC emerged with the intent to address the psychological oppression experienced by black South Africans is warranted. This intent bears a striking similarity to the Black Consciousness philosophy, a philosophy that equally sought to address the mental state of the oppressed black South Africans. Corresponding to the Black Consciousness philosophy, it is likely that the BMC emerged with the view to liberate black South Africans from the mental condition of an inferiority complex and their perception of themselves as less than human. In its inception, the BMC equally insisted that black is beautiful. 
Through research and education, the BMC made a contribution towards the development of black South African ministers in the MCSA. That the BMC hosted seminars on topics such as 'the Africanisation of the Church' is not only irrefutable, but also accounts for the preceding claim (cf. Balia 1994:163; Forster 2008:12; Pritchard 2014:286; Venter 2007:54). Clearly, the seminars initiated by the BMC, which educated black South African ministers, prove to have been significant in the life of the MCSA. Therefore, the interest on education within the Black Consciousness philosophy which is evident in Biko's involvement both with FEDSEM and UCM bears on how the BMC educated black South African ministers. Furthermore, in his response to the crisis in black education which followed the Soweto Uprising of 1976, Ernest Baartman, the president of the BMC pleaded with parents to encourage their children to return back to school (Madise 2014:121). Though it is unclear whether the BMC was in solidarity with the students who protested the enforcement of Afrikaans as a medium of instruction in schools, the interest of the BMC about the education of children is conclusive.

It is argued that the BMC emerged as a response to the issue of racism in the MCSA, a church that professed itself 'one and undivided' (Balia 1991:86; Bailie 2009:42, 43). Making a similar argument, but differently, Forster states that the BMC emerged to refute segregation and apartheid (Forster 2008:12; 2011:46; cf. Bentley 2014:4; Methodist Church of Southern Africa 1958:202; 1982:379; Pritchard 2014:285-286, 288-290). Unlike Bailie, surprisingly, Forster does not clearly argue that whiteness or white supremacy is the underlying factor that the BMC aimed to address. Against Forster's position, I find Bailie's argument appealing, as it highlights racism as the contentious issue at the time of the BMC's formation (Bailie 2009:42). Of significance is Cone's view that the black theology of liberation is a theology whose sole purpose is to address the oppression of black people. The latter view resonates with the BMC's quest for the liberation of black South Africans from racism (Cone 1997:31; cf. Roberts 2005:11). On the black liberation theological level, it is argued that God tends to intervene decisively against forms of oppression and exploitation (Mgojo 1977:28; Mosala 1996:21). Again, the theme of the liberation of black South Africans from racism which is carried in the black theology of liberation is brought to bear on the BMC.

In his contribution, Black theology and human identity, Cornel West calls for the demise of white supremacy (West 1999a:16). Such a call is set as a prerequisite for the realisation of liberation in the context of African Americans. For him, white supremacy is the creative fusion of rationality, scientificity and objectivity which prohibits the intelligibility and legitimacy of the idea of black beauty and intellectual capacity to produce knowledge (West 1982:48). Against the idea that whiteness exclusively provides the reliable rationality and objectivity that produces knowledge, the BMC sought to redress the domination of whiteness in the production of decisions in the MCSA (Forster 2008:11-12; Pritchard 2014:285; Theilen 2003:28). In light of Cornel West's view on the liberation in the context of theology and philosophy, it is reasonable to argue that the Black Consciousness philosophy and the black theology of liberation inspired the BMC to struggle for the production of a 'liberative' decision in the MCSA, namely, the decision of electing black South African ministers as bishops.

Given the present reflection on the Black Consciousness philosophy, black theology of liberation and the BMC, a case for their interconnectedness is merited. Not only does this reflection shed light on the reasons for the emergence of the $\mathrm{BMC}$, it equally shows the prophetic operational framework of the BMC, that is, its objectives which include the view to:

- Be an interlocutor of liberation of black South Africans

- Redress the oppression of black South Africans which was based on race

- Refute the negation of blackness and the affirmation of whiteness

- Demand the infusion of black South Africans with pride and dignity

- Identify white oppressive socio-economic structures

- Critique the complicity of black South Africans in their oppression

- Liberate black South Africans from their servitude mentality

- Redress racism by calling for the demise of white supremacy

- Promote black thinking and leadership in the MCSA

- Promote the education of black South African children

- Establish a close working relationship between black theologians, philosophers and activists.

\section{Navigating the prophetic voice of the BMC in post-apartheid South Africa}

As mentioned above, the argument that the BMC has made a valuable contribution to South Africa during the institutionalised oppression of black South Africans during the apartheid rule is irrefutable. Notwithstanding the preceding argument, the hypothesis of this article has been that the prophetic voice of the BMC is crucial in South Africa today.

\section{Deconstructing and constructing the black identity of black South Africans}

On the issue of black identity, particularly when considered in the light of the South African history of colonialism and apartheid, two critical questions to ask are: Did black South Africans identify themselves as black in precolonial South Africa?; Was the designation 'black' constructed and imposed on black South Africans by the Dutch and British colonists?

It is generally accepted that the concept of Ubuntu, 'humanness', expresses the identity of black South Africans prior to the arrival of the colonists in South Africa (Dolamo 2013:5; Ng'weshemi 2002:39). The preceding concept is based on the expression, umuntu ngumuntu ngabantu, [a person is a person through other persons] (Broodryk 
2008:41; Dolamo 2013:2). That this expression identified black South Africans as umuntu [a person], shows how they certainly had an opinion of who they were prior to the arrival of the colonists. Put differently, prior to the arrival of the colonists in South Africa, black South Africans viewed themselves as being 'human'. Regarding the designation 'black', worthy of note is the argument made by the president of the BMC, Mzwandile Molo (2014), that prior to the dawn of the arrival of colonists, there was no evidence of any other skin pigmentation to which black South Africans could compare themselves. The idea that black South Africans perceived themselves as human beings supports the latter argument. Therefore, connected to the arrival of the colonists was the creation of the skin pigmentation which not only altered the concept of Ubuntu, but also served to differentiate and segregate the settlers from black South Africans (cf. Dolamo 2013:5; Ng'weshemi 2002:39). Thus, Asante and Hall hold that blackness has nothing to do with the skin pigmentation (Asante \& Hall 2011:29; cf. Cone 1989:151-152). In other words, as a conceptual category, the designation 'black' was informed by the skin pigmentation (De Kock 2011:31; Vellem 2012:351). Based on the argument that prior to the advent of the colonists in South Africa, black South Africans identified themselves as being 'human', suffice it to say, the designation 'black' is an imposed one.

Given the legacy of colonialism and apartheid, a pertinent question to pose is: What does it mean to be black in postapartheid South Africa? As Boesak correctly perceived, to be black in apartheid South Africa meant not only to be a 'nonwhite', but also a 'non-person' (Boesak 1977:26). The designation 'black' did not only mean being less than a human, it was also an imposition which carried with it the portrayal of the colonists as being superior to the 'black' race and subsequently created out of black South Africans the second-class citizens (Dolamo 2013:6; Vellem 2012:348). No wonder that, it is correctly claimed that 'blackness was identified with negativity, being seen as evil and anything derogatory' (Masenya [ngwan'a Mphahlele] 2004:69). To support this claim, Masenya (ngwan'a Mphahlele) refers to her conversation with Miescher. It is pointed out that in the white culture, blackness is associated with bad mystique, danger, negativity and evil, hence, a black goat is viewed as a bad one (Blackie)' (Masenya [ngwan'a Mphahlele] 2004:69; cf. Miescher 1995). Regarding the preceding view about a black goat, worthy of note is Malcolm X's remark: '[T]his white mercenary had a little black goat that he named 'nigger' (Malcolm X in Breitman 2010:124). The association of a black goat with a person of African descent illustrates how the designation 'black' was viewed in a negative light. Clearly, in this case, both African Americans and black South Africans were identified as being 'non-white', 'a non-person', 'less than a human', 'evil' and 'bad'.

A similar point is made by Vellem on being relegated to second-class citizenship; Saayman links the issue of poverty to the perception of black South Africans as being less than human (Saayman 2011:178; cf. Vellem 2012:348). He argues that the identity of black South Africans ought to be rooted in humanness. However, Saayman does not discuss such an identity in relation to the challenge of poverty in a convincing manner, as Hopkins assuredly does. In his attempt, Hopkins argues that the idea of the preferential option for the poor should be employed to redefine the humanity of black people who continue to struggle to attain basic material possessions (Hopkins 2002:54). Against the designation of a 'non-person' that has been imposed on black South Africans, an identity that is undergirded by the idea of 'the preferential option for the poor' and that calls for solidarity with the oppressed people in the margins of society, is compelling (Cone 1989:151-152; 1992:21, 53; Tshaka 2014:1, 2). The preceding argument is compelling, mainly because it offers a liberated oriented definition of black identity.

Furthermore, the derogatory words that have been employed to identify black South Africans during the colonial and apartheid system are noticed in post-apartheid South Africa. For instance, the designation, 'heathen', which in the earliest Arabic context meant a 'non-believer', was used in the South African apartheid setting as a derogatory word to refer to black South Africans (Hopkins 2000:32; Setiloane 1970:325; Subreenduth 2009:120; Van den Berghe 1965:10). Thus, Cabrita argues that it was the mandate of the early Christian converts, amakholwa [the believers], to educate and convert the 'uncivilized and heathen' black South Africans (Cabrita 2014:68). It comes as no surprise, therefore, that the Xhosa Methodist Service Book presents a liturgy that commences with a reference to wickedness and the need to be converted. The text reads: 'Okhohlakeleyo akuguquka ekukhohlakaleni kwakhe akwenzileyo, enze okufanelekileyo nokulungileyo, yena uya kulondoloza umphefumlo wakhe ebomini' [But if a wicked person turns away from the wickedness they have committed and does what is just and right, they will save their life] (Curnick 1926:11; cf. Ez 18:27). In this case, the Xhosa liturgy that was and is still used by black South Africans in the MCSA, bears on the argument that amakholwa [the believers], had a duty to convert the heathens (cf. Cabrita 2014:68). In the process of converting the heathens, it is likely that the Xhosa liturgy was not employed with adverse intentions. However, that such a liturgy identified black South Africans as okhohlakeleyo [wicked person], who is a heathen, is an irrefutable reality. Therefore, the usage of the preceding liturgy in postapartheid South Africa perpetuates the identification of black South Africans with wickedness.

On the issues of the imposition of blackness by the colonists to black South Africans in the MCSA, Mtshiselwa has convincingly illustrated how a European produced church song imported into a South African context, depicts an influence of whiteness over blackness (Mtshiselwa 2011:682). The Xhosa song 'Ndikhokele O Yehova' (cf. Davis 1926:197), which is a translation and a reconstruction of the song 'Guide me O thou great Jehovah' (cf. Williams 1983:437) shows how, against the African value of communalism, an individualist approach to God was imposed onto black South Africans. The fact that the verb 'ndikhokele' [guide me] 
is in singular form, accounts for the imposition of the value of individualism which is in contrast to the highly regarded value of communalism that constitutes blackness (Mtshiselwa 2011:683). Thus, Dolamo's argument that the colonists both altered and distorted the value of communalism which is rooted in the concept of Ubuntu, 'humanness' is compelling (Dolamo 2013:5, 7). To counter such distortion, it is argued that the acceptance of blackness includes the affirmation of the African value of communalism (Cone 1999:256; cf. Malcolm X 1965:165; King 1967). Concurring with Cone, the preceding value defines people's humanity.

Importantly, the need for the deconstruction and reconstruction of the black identity may be considered by the BMC. Firstly, the legacy of the perception of black South Africans as less than human which not only presented white people as superior to the 'black' race, but also created out of black South Africans the second-class citizens, is perturbing. The poor living conditions of the working-class people who are labouring both on the farms and in the mines, confirms for the preceding legacy. Interestingly, the above-mentioned prophetic operational framework of the BMC demands a critique of the poor conditions which the farmers and miners often protest against. Secondly, the view that the preferential option for the poor should be employed to redefine the humanity of black South Africans shows an area in which the BMC could express a prophetic voice. Thirdly, the Xhosa liturgy that continues to cast a black South African as okhohlakeleyo, [wicked person], reveals the need, on the part of the BMC, to demand the infusion of black South Africans with pride and dignity. Fourthly, the imposition of the problematic value of individualism which is in contrast to the value of communalism, that is evident in the hymn, 'Ndikhokele O Yehova', is detectable in the capitalistic selfenriching approach to the accumulation of wealth among black South Africans. Therefore, the BMC may serve as an interlocutor that highlights the way that the construction of individualism adversely impacts on black South Africans, as will be shown below. Based on these four areas, in which the BMC could be prophetic, the argument that the BMC needs to serve as an interlocutor of liberation in post-apartheid South Africa is warranted.

\section{Mind the share of shame of some black South African political elites}

The influence of whiteness on blackness is often critiqued in South Africa, whilst blackness is hardly scrutinized (Molo 2014). Based on the preceding observation, an investigation on how some persons belonging to the black South African political elite have shortcomings is necessary. The subject of the rise of black South Africans to the political positions of power justifies the reflection on the metaphor of the 'castle' which is employed here to refer to government. It is argued that entering the 'castle' of the mainstream, that is, enjoying the privileges of being part of the government, whilst pursuing the liberation of the oppressed people, can present damaging possibilities (Hopkins 2002:163). In the preceding scenario, the pursuit of the liberation of the poor places the emerging black elites in a position of being anxious about the risk of losing the privileges gained in the 'castle' (Hopkins 2002:163; cf. Cone 1999:256). The metaphor of the 'castle' resonates with the situation of black South Africans. Klein holds that in the transition to democracy, the government of the so-called transitional countries, including South Africa, was 'given the key to the house, but not the combination to the safe' (Klein 2007:204). The implication of the latter statement is that black South African political elites were given the keys to the 'castle', as Hopkins would argue, but not the access to the complete wealth of the country. Interestingly, even though the wealth of the country is not in the hands of the majority of South Africans, the preceding political elites have evidently become wealthy, whilst many black South Africans remain poor in post-apartheid South Africa. That according to the latest statistics, $61.4 \%$ of black South Africans are poor, compared to $4.35 \%$ of white persons, supports the submission that many black South Africans are poor (Modise \& Mtshiselwa 2013:359; Mtshiselwa 2014:63; Stats SA 2012:71). In this case, the prophetic voice would be the objection to the economic inequality in South Africa (Goba 1973:73; cf. Pang 2007:128). In the light of the gap between the rich black South African political elites and the poor, it is reasonable to argue that the prophetic voice of the BMC is crucial in post-apartheid South Africa.

Worthy of note is De Kock's argument that the liberal capitalist project of the early 21st century in a neo-colonial global order of whiteness has now been extended to black South African elites, namely Sexwale and Motsepe, among others (De Kock 2011:31). Concurring with Vellem who, in turn, is sympathetic to De Kock's argument, the observation of the capitalist selfenriching tendency by black South African political elites is warranted (Vellem 2012:359). Suffice it to say, not only has Motlana, for instance, enjoyed the shares in the company, New Africa Investments Limited (NAIL) and the flirtation with the Anglo-American group's Southern Life, he has also added to his financial stable the African Merchant Bank and Theta's usury-busting Theta micro-lending activities (Bond 2000:31). Also, in 1999, Ramaphosa's ex-colleagues at NAIL, Motlana, Jonty Sandler, Moseneke, and Zwelakhe Sisulu gave themselves R35 million each in personal bonuses for good performance (Bond 2000:32). Furthermore, the case of Ramaphosa presents a compelling illustration of how black South African political elites rose to the position of power at the dawn of democracy. Regarding how black South African elites benefited from Black Economic Empowerment (BEE), Lonmin extended a \$304 million loan to Ramaphosa's Shanduka group to establish the BEE status (Steyn 2012). Based on the case of Ramaphosa, Motlana, Jonty Sandler, Moseneke and Zwelakhe Sisulu, the earlier argument made by De Kock on the liberal capitalist project which has been extended to black South African elites is compelling (De Kock 2011:31). No doubt, the tendency by black South African political elites to exclusively enrich their finances, in the midst of poverty is indisputable. Therefore, in the light of the objective of critiquing the complicity of black South Africans in their oppression, the argument that the BMC needs to speak against the latter tendency, is compelling. 
Furthermore, noticeable in the 'castle' or government of South Africa is the corruption of some of the government officials. It is estimated that R28 million will be recovered from the investigated cases that relate to irregular awarding and administration of land reform grants (Zuma 2012:2). In such cases, the names of black South African elites who are implicated were not disclosed. Nonetheless, Ndaliso reports that a KwaZulu-Natal business man, Roshen Sewpersadh, and three government officials, Promise Phumzile Makhanya, Bhekumuzi Patrick Masoka and Sibusiso Chapi, were arrested for the irregular awarding and administration of land reform grants and released on bail (Ndaliso 2011:1; cf. Mohoebi 2011:1-3; Zuma 2012:2). Given the preceding cases, it is clear that some black South Africans who are in the position of power have been involved in corruption. Thus, the argument that some of black South Africans in the position of power are corrupt is merited. It is therefore argued here that the BMC needs to speak out and object this corruption, as it shows the complicity of black South Africans in their oppression.

\section{Unmasking racism - the struggle of the BMC}

Molo (2014) holds that in a country which is easily regarded as post-racial, the prophetic task of the BMC is to unmask the racism which is often assumed to have receded in post-apartheid South Africa. Snyman's view that racism has not receded in the democratic and post-racial South Africa validates Molo's position (Snyman 2002:79; 2011a:4, 7; 2011b:467). However, unlike Molo, Snyman (2011a) advocates the unmasking of whiteness. For him whiteness is:

[A] location of structured advantages of race privilege; a standpoint or a place from which white people look at themselves, at others and at society; a set of cultural practices that are usually unmarked and unnamed. (p. 10; cf. 2011b:467)

Surprisingly, Snyman does not explicitly state that racism should be unmasked, as Molo argues, but whiteness. Nonetheless, before we proceed with the discussion on the issue of unmasking racism, a definition of the term, racism would be in order.

Hoyt (2012:229) argues that the definition of racism as a system of advantage based on race is plausible as it suggests that racism is not an ideology which is based on racial prejudice (cf. Wellman 1993). Rather, racism is a system that involves policies and practices as well as the beliefs and actions of individuals who are in a position of power and privilege (Hoyt 2012:229). In contrast to racism, racial prejudice is a 'preconceived judgment or opinion, often based on limited information' (Tatum 1997:9). Based on these definitions, racism has less to do with not liking or hating another person of a different race. Furthermore, it is argued that racism operates with a view to benefit white persons as a group over the entire group of non-white people (Tatum 1992:3). It is therefore reasonable to view racism as the system of privilege that is based on race which adversely impacts the entire race group. The implication of the latter view is that, if an individual's actions do not adversely impact the entire group, such actions may not be regarded as a portrayal of racism.

Against the distinction made by Tatum (1997:9) on racism and racial prejudice, Blum (2002:37) argues that racism is a combination of racial prejudice and power. This position implies that the black elites who have power could be as racist as their white counterparts. However, such an implication would convincingly be refuted by scholars, such as Wellman, Tatum and Hoyt, as they maintain that racism is about the power which adversely impacts the lives of the entire race group, as shown above. Since black South African elites could find it difficult to oppress the entire race of white people, it would be implausible to view them as racist. In the light of the global reality that wealth, resources and power are predominantly in the possession of the white persons, the black race does possess the power that could harmfully impact the entire group of the white race. In this case, it would be plausible to argue that black South Africans could racially prejudice white people. However, suffice it to say, black South Africans are not in a position to create a system of advantage that is based on race which could adversely impact on the entire group of white people, both nationally and globally.

On the issue of racism, Matthews's (2011) argument that the privilege and legacy of whiteness are passed down from generation to generation suggests that the continuation of white privilege in post-apartheid South Africa is indisputable (Matthews 2011). Making a similar argument, but more descriptively, Mclntosh (1992) argues that white privilege as alluding to:

$[T]$ he concrete benefits of access to resources and social rewards and the power to shape the norms and values of society that whites receive, tacitly or explicitly, by virtue of their position in a racist society. (p. 79)

Interestingly, on the issue of the privilege of accessing resources in the MCSA, Forster (2008) remarks:

The current debate on equitable stipends in the MCSA, as well as the stark reality that a black Methodist minister will serve on average 3000 members, and 12 societies, whereas a white Methodist minister will serve on average 350 members and a single society, show that there are still very different standards for black and white Methodists. (p. 23)

Concurring with Forster, a hint at a system that places white ministers in a position of benefit and privilege in which they are often not stationed in a context with 3000 members is being made here. Also, many a white ordained minister is often not stationed in the rural area wherein poverty is at its peak. Therefore, it means that in terms of the stationing system in the MCSA, white ministers are immune to being placed in a context of poverty where they could possibly leave without a source of income. In that case, the task of the BMC in the post-apartheid South Africa is to criticise the preceding system, as it continues to privilege white ministers.

Noteworthy, in the document, The reconciliation of ministries in the covenant, presented by the members of the Church 
Unity Commission (CUC), it is stated that 'God has been calling and continues to call his Church to be a community that transcends all barriers of denomination and race' (CUC 1980:31). At the time in which the preceding statement was made, the caucus bodies such as the BMC where critical of the attempts to refute the system of apartheid which entrenched inequality in both Church polity and secular law. Based on the call for the Church to transcend barriers of race, the constructive role of the BMC in the future of a multiracial society of the post-apartheid South Africa may be disputed. However, if the argument made by Forster (2008:23) on the persistent inequality in the MCSA around the issues of stipends and stationing which adversely impact on the black ministers, the role and necessity of the BMC would be justified.

\section{Conclusion}

The reflection of the present article has been inspired by the celebration of the 40th year of the existence and activism of the BMC. As such, this article sets out to argue that the $\mathrm{BMC}$ is a crucial interlocutor of liberation in the so-called democratic and post-racial South Africa. Of significance is the interconnectedness of the Black Consciousness philosophy, the black theology of liberation and the BMC, which informed the prophetic operational framework of the BMC, namely, its objectives. It is based on such a framework, that the possible prophetic role of the BMC is imagined in post-apartheid South Africa. In its expression of the possible prophetic voice in present South Africa, it is critical that the $\mathrm{BMC}$ attempts to deconstruct and reconstruct black identity; minding the share of shame of black South Africans political elites; and unmasking the persistent racism in South Africa.

\section{Acknowledgements}

I would like to thank my God, whose grace sustains me in my scholarship. Much gratitude goes to my lovely wife, Siphumle (Manzimande) for her continued support.

\section{Competing interests}

The author declares that he has no financial or personal relationships which may have inappropriately influenced him in writing this article.

\section{References}

Asante, M.K. \& Hall, R.E., 2011, Rooming in the master's house: Power and privilege in the rise of black conservatism, Paradigm Publishers, Boulder, CO/London.

Bailie, J., 2009, 'The impact of liberation theology on Methodism in South Africa with regard to the Doctrine of Christian Perfection', PhD Thesis, Dept. of Systematic Theology, University of South Africa.

Balia, D.M., 1991, Black Methodists and white supremacy in South Africa, Madiba Publishers, Durban.

Balia, D.M., 1994, 'The witness of the Methodist Church in South Africa', International Review of Mission 83(328), 163-165. http://dx.doi.org/10.1111/j.1758-6631. 1994.tb02357.x

Bentley, W., 2014, 'Methodism and transformation in South Africa: 20 years of constitutional democracy', HTS Teologiese Studies/Theological Studies 70(1), 1-8. http://dx.doi.org/10.4102/hts.v70i1.2673

Biko, S.B., 1979, I write what I like, Heinemann, London.

Biko, S.B., 2004, I write what I like, Picador Africa, Johannesburg
Blum, L.A., 2002, 'I'm not a racist, but ...' the moral quandary of race, Cornell University Press, Ithaca, NY.

Boesak, A., 1977, Farewell to innocence, Ravan Press, Johannesburg.

Bond, P., 2000, Elite transition: From apartheid to neoliberalism in South Africa, University of Natal Press, Pietermaritzburg.

Breitman, G., 2010, Malcolm X speaks, Pathfinder, New York, NY.

Broodryk, J., 2008, Understanding South Africa: The Ubuntu way of living, Ubuntu School of Philosophy, Pretoria.

Cabrita, J., 2014, Text and authority in the South African Nazareth Church, Cambridge University Press, New York, NY. http://dx.doi.org/10.1017/CBO9781107294318

Carter, W., 2010, Theology for a violent age: Religious beliefs crippling African American youth, iUniverse Books, Bloomington, IN.

Church Unity Commission (CUC), 1980, 'The reconciliation of ministries in the covenant', In Touch 2(13), 25-31.

Cone, J.H., 1989, Black theology and black power: Twentieth anniversary edition, Harper and Row, New York, NY.

Cone, J.H., 1992, The blues and the spirituals, Orbis books, Maryknoll, NY.

Cone, J.H., 1997, Black theology and black power, rev. edn., Orbis Books, Maryknoll, NY.'

Cone, J.H., 1999, 'Looking back, going forward: Black theology as public theology', in D.N. Hopkins (ed.), Black faith and public talk: Critical essays on James H. Cone's black theology and black power, pp. 246-260, Orbis Book, Maryknoll, NY.

Curnick, T. R., 1926, Incwadi Yombedesho Kunye Neminye Imibedesho Namaculo Emiselwe Ibandla Lamawesile Ase South Africa: Ibhalwe NgesiXhosa, Methodist Book Deport and Publishing House, Cape Town.

Davis, W. S., 1926, 'Ndikhokele O Yehova', in T. R. Curnick (ed.), Incwadi Yombedesho Kunye Neminye Imibedesho Namaculo Emiselwe Ibandla Lamawesile Ase South Africa: Ibhalwe NgesiXhosa, p. 797, Methodist Book Deport and Publishing House, Africa: Ibhatwe Town.

De Gruchy, J.W., 1997, 'Grappling with a colonial heritage: The English-speaking churches under imperialism and apartheid', in R. Elphick \& T.R.H. Davenport (eds.), Christianity in South Africa: A political, social, and cultural history, pp. 155(eds.), Christianity in South Africa: A political, social,
172, University of California Press, Oakland, CA.

De Gruchy, J.W. \& De Gruchy, S., 2004, The Church struggle in South Africa: 25th anniversary edition, SCM, London.

De Kock, L., 2011, 'Capitalism's not a white thing', Mail and Guardian, 16-22 September, p. 31.

Denis, P. \& Duncan, GA., 2011, The native school that caused all the trouble: A history of the federal theological seminary of Southern Africa, Cluster Publications, Pietermaritzburg.

Dolamo, R., 2013, 'Botho/Ubuntu: The heart of African ethics', Scriptura 112(1), $1-10$.

Duncan, G.A., 2013, 'Passive-aggressive resistance against apartheid at the federal theological seminary of Southern Africa', Acta Theologica 33(1), 54-78.

Forster, D., 2008, 'Prophetic witness and social action as holiness in the methodist church of Southern Africa's mission', Studia Historiae Ecclesiasticae 34(1), 1-24.

Forster, D., 2011, 'Evangelism, mission, and discipleship in Southern Africa: How hope is overcoming tragedy', in P.W. Chilcote (ed.), Making disciples in a world parish: global perspectives on mission and evangelism, pp. 39-78, Pickwick Publications, Wiobal perspectives on mission and
Wiptock Publishers, Eugene.

Goba, B., 1973, 'Corporate personality: Ancient Israel and Africa', in B. Moore (ed.), Black theology: The South African voice, pp. 65-73, C. Hurst \& Co., London.

Goba, B., 1986, 'The Black Consciousness Movement: its impact on black theology', in I. Mosala \& B. Thagale (eds.), The unquestionable right to be free: Essays in black theology, pp. 58-69, Skotaville Publishers, Johannesburg.

Gqubule, S., 1974, 'What is black theology?' Journal of Theology for Southern Africa $8,16-23$.

Hoyt Jr. C., 2012, 'The pedagogy of the meaning of racism: Reconciling a discordant discourse', Social Work 57(3), 225-234. http://dx.doi.org/10.1093/sw/sws009

Hopkins, D.N., 1990, Black theology USA and South Africa, Orbis Books, Maryknoll, NY.

Hopkins, D.N., 2000, s.v. 'Black consciousness', in V. Fabella \& R.S. Sugirtharajah (eds.) Dictionary of third world theologies, Orbis Books, Maryknoll, NY, p. 32.

Hopkins, D.N., 2002, Heart and head: Black Theology, past, present and future, Palgrave, New York. http://dx.doi.org/10.1057/9780312299187

Himes, J.S., 1971, 'A theory of racial conflict', Social Forces 50(1), 53-60. http://dx.doi. org $/ 10.1093 / \mathrm{sf} / 50.1 .53$

Isaacs, H., 1975, Idols of the tribe: Group identity and political change, Harper \& Row, New York., NY

King J.., M.L., 1967, Beyond Vietnam, a pamphlet of the Clergy and Laymen Concerned about Vietnam (CALCAV), Union Theological Seminar, New York, April 04

Klein, N., 2007, 'Democracy born in chains: South Africa's constricted freedom', in N. Klein (ed.), The shock doctrine: The rise of disaster capitalism, pp. 194-217, Metropolitan Books, Henry Holt \& Company, New York, NY.

Kretzschmar, L., 1986, The voice of black theology in South Africa, Ravan, Johannesburg.

Madise, M., 2014, 'The leadership of the Methodist Church of Southern Africa during the 1980s and 90s: The transition from apartheid to the democratic era in South Africa', Studio Historiae Ecclesiasticae 40, 117-127.

Malcolm, X., 1965, Malcolm X speaks, Grove Press, New York, NY. 
Masenya (ngwan'a Mphahlele), M., 2004, How worthy is the woman of worth? rereading Proverbs 31:10-31 in African-South Africa, Peter Lang, New York, NY.

Masenya (ngwan'a Mphahlele), M., 2008, 'An African-conscious female's reading of Steve Biko', in C.W. du Toit (ed.), The legacy of Stephen Bantu Biko: Theological challenges, pp. 114-155, Research Institute for Religion and Theology, University of South Africa, Pretoria.

Matthews, S., 2011, 'Inherited or earned advantage', Mail \& Guardian, viewed 19 October 2011, from http://mg.co.za/article/2011-09-12-inherited-or-earnedadvantage

McIntosh, P., 1992, 'White privilege and male privilege: A personal account of coming to see correspondences through work in women's studies', in M.L. Andersen \& P.H. Collins (eds.), Race, class, and gender: An anthology, pp. 70-81, Wadsworth, Belmont, TN.

Methodist Church of Southern Africa, 1958, Minutes of Conference of the Methodist Church of Southern Africa, The Methodist Publishing House, Cape Town.

Methodist Church of Southern Africa, 1982, Minutes of Conference of the Methodist Church of Southern Africa, The Methodist Publishing House, Cape Town.

Mgojo, E.K.M., 1977, 'Prolegomenon to the study of Black Theology', Journal of Theology for Southern Africa 21, 25-32.

Miescher, E., 1995, 'Communication with Masenya (ngwan'a Mphahlele)', Audio, 05 May, Evanston.

Modise, L. \& Mtshiselwa, N., 2013, 'The Natives Land Act of 1913 engineered the poverty of black South Africans: A historico-ecclesiastical perspective', Studio Historiae Ecclesiasticae 39(2), 359-378.

Mohoebi, E., 2011, Forfeiture Unit seizes 2 KwaZulu-Natal farms as Department intensifies its fight against fraud and corruption, DRDLR, Pretoria.

Molo, M., 2014, 'Interview with Mzwandile Molo on the Black Methodist consultation', Audio, 11 December, Johannesburg.

Mosala, I.J., 1996, 'Wealth and poverty in the Old Testament - A black theological perspective', Journal of black theology in South Africa 5, 16-22.

Motlhabi, M., 2007, African theology/black theology in South Africa: Looking back, moving on, Unisa Press, Pretoria.

Mtshiselwa, N., 2011, 'Towards an indigenous (Xhosa) South African biblical scholarship', Old Testament Essays 24(3), 668-689.

Mtshiselwa, N., 2014, 'A post-apartheid nation in chains? Relevance of Lucky Dube's Mickey Mouse Freedom in reconfiguring forms of oppression in South Africa today', Studia Historiae Ecclesiasticae 40(1), 57-76.

Ndaliso, C., 2011, 'Land fraud case set for 2012', The Witness, 03 October, pp. 1-3.

Ng'weshemi, A.M., 2002, Rediscovering the human: The quest for a Christo-theological anthropology in Africa, Peter Lang, New York, NY

Pang, S.Y., 2007, 'A significance of South African black theology as a postcolonia theology in the making', Theological Forum 50, 115-133.

Pritchard, J., 2014, Methodists and their missionary societies 1900-1996, Ashgate, Farnham.

Roberts, J.D., 2005, Liberation and reconciliation: A black theology, 2nd edn. Westminster John Knox Press, Louisville, KY.

Saayman, W., 2011, 'Being human together in democratic South Africa: Umuntu ngumuntu ngabantu', Journal of Gender and Religion in Africa 17(1), 170-188.

Setiloane, G.M., 1970, 'A personal encounter with racism', International Review of Mission 59(235), 324-332. http://dx.doi.org/10.1111/j.1758-6631.1970. of Mission

Snyman, G.F., 2002, 'The body, rhetoric and postcolonial criticism', Religion \& Theology 9(1/2), 63-88. http://dx.doi.org/10.1163/157430102X00043

Snyman, G.F., 2011a, 'Empire and a hermeneutics of vulnerability', Studia Historiae Ecclesiasticae 37(suppl.), 1-20.

Snyman, G.F., 2011b, "Looking into black eyes and feel the embarrassment' A selected and selective reading of the Africana Bible', Old Testament Essays 24(2), 464-491.
Statistics South Africa (Stats SA), 2012, Social profile of vulnerable groups in South Africa 2002-2011, Statistics South Africa, Pretoria.

Steyn, L., 2012, 'Lonmin unlucky in BEE love', Mail \& Guardian, viewed 15 January 2014, from http://mg.co.za/article/2012-12-07-00-Ionmin-unlucky-in-bee-love

Subreenduth, S., 2009, 'Post-apartheid dilemmas: Black teachers theorizing social justice', in R.S. Coloma (ed.), Postcolonial challenges in education, pp. 119-138, Peter Lang, New York, NY.

Tatum, B.D., 1992. 'Talking about race, learning about racism: The application of racial identity development theory in the classroom', Harvard Educational Review 62(1), $1-24$.

Tatum, B.D., 1997, Why are all the black kids sitting together in the cafeteria?: And other conversations about race, Basic Books, New York, NY.

Theilen, U., 2003, 'Gender, race, power and religion: Women in the methodist church of Southern Africa in post-apartheid society', PhD Thesis, Fachbereich Gesellschaftswissenschaften und Philosophie, Philipps-Universität, Marburg.

Tshaka, R.S., 2009, 'Academic theology as the yardstick of being reformed in South Africa today: An appreciative critique of Calvin on the occasion of his 500th Birthday', Studia Historiae Ecclesiasticae 35, 1-16.

Tshaka, R.S., 2010a, 'Do our theological methodologies help us to deal with situations of violence in black communities, specifically Afrophobia', Journal of Theology for Southern Africa 138, 124-135.

Tshaka, R.S., 2010b, 'The continued relevance of black liberation theology for democratic South Africa today', Scriptura 105, 532-546. http://dx.doi. org/10.7833/105-0-155

Tshaka, R.S., 2014, 'On being African and reformed? Towards an African reformed theology enthused by an interlocution of those on the margins of society', HTS Teologiese Studies/Theological Studies 70(1), 1-7. http://dx.doi.org/10.4102/hts. v70i1.2070

Van den Berghe, P.L., 1965, South Africa: A study in conflict, University of California Press, Berkeley, CA.

Vellem, V., 2012, 'Interlocution and black theology of liberation in the 21st century: A reflection', Studia Historiae Ecclesiasticae 38, 345-360.

Venter, D., 2007, Inverting the norm: Racially-mixed congregations in a segregationist state, Galjoen Academic Press, Cape Town.

Villa-Vicencio, C., 1996, The spirit of freedom: South African leaders on religion and politics, University of California Press, Berkeley/Los Angeles, CA.

Wellman, D., 1993, Portraits of white racism, 2nd edn., Cambridge University Press, Cambridge. http://dx.doi.org/10.1017/CBO9780511625480

West, C., 1982, 'The genealogy of modern racism', in C. West (ed.), Prophecy deliverance: An Afro-American revolutionary Christianity, pp. 47-68, Westminster deliverance: An Afro-Amer
Press, Philadelphia, PA.

West, C., 1999a, 'Black theology and human identity', in D.N. Hopkins (ed.), Black faith and public talk: Critical essays on James H. Cone's Black theology and black power, pp. 11-19, Orbis Books, Maryknoll, NY.

West, C., 1999b, The Cornel West reader, Civitas Books, New York, NY.

West, G., 2010, 'The legacy of liberation theologies in South Africa, with an emphasis on biblical hermeneutics', Studia Historiae Ecclesiasticae 36, 157-183.

Williams, W., 1983, 'Guide Me Oh Thou Great Jehovah', in Representatives from the British Methodist Conference, Baptist Union, Churches of Christ, Church of England, Congregational Federation, Methodist Church in Island, United Reformed Church and Wesleyan Reformed Union (eds.), Hymns and psalms: A methodist and ecumenical hymn book, p. 437, Methodist Publishing House, London.

Wilson, L., 1991, 'Bantu Stephen Biko: A life', in B. Pityana, M. Ramphele, M. Mpumlwana \& L. Wilson (eds.), Bounds of possibility: The legacy of Steve Biko and black consciousness, pp. 15-77, David Philip, Cape Town.

Woods, D., 1978, Biko, Random House, New York, NY.

Woods, D., 1987, Biko: The true story of the young South African martyr and his struggle to raise black consciousness, Henry Holt Books, New York, MY.

Zuma, J.G., 2012, Written replies by President Zuma submitted to Parliament: 30 September 2012, The Presidency, Republic of South Africa, Pretoria. 